University of Windsor

Scholarship at UWindsor

\title{
Species differences in the songs of the critically endangered Niceforo's Wren and the related Rufous-and-white Wren
}

\author{
Sandra V. Valderrama \\ Jorge E. Parra \\ Daniel J. Mennill \\ University of Windsor
}

Follow this and additional works at: https://scholar.uwindsor.ca/biologypub

Part of the Biology Commons

\section{Recommended Citation}

Valderrama, Sandra V.; Parra, Jorge E.; and Mennill, Daniel J., "Species differences in the songs of the critically endangered Niceforo's Wren and the related Rufous-and-white Wren" (2007). Condor, 109, 4, 870-877.

https://scholar.uwindsor.ca/biologypub/1130

This Article is brought to you for free and open access by the Department of Biological Sciences at Scholarship at UWindsor. It has been accepted for inclusion in Biological Sciences Publications by an authorized administrator of Scholarship at UWindsor. For more information, please contact scholarship@uwindsor.ca. 


\title{
SPECIES DIFFERENCES IN THE SONGS OF THE CRITICALLY ENDANGERED NICEFORO'S WREN AND THE RELATED RUFOUS-AND-WHITE WREN
}

\author{
Author(s): SANDRA V. VALDERRAMA, JORGE E. PARRA, DANIEL J. \\ MENNILL
}

Source: The Condor, 109(4):870-877.

Published By: Cooper Ornithological Society

https://doi.org/10.1650/0010-5422(2007)109[870:SDITSO]2.0.CO;2

URL: http://www.bioone.org/doi/

full/10.1650/0010-5422\%282007\%29109\%5B870\%3ASDITSO $\% 5 D 2.0 . \mathrm{CO}$

\%3B2

BioOne (www.bioone.org) is a nonprofit, online aggregation of core research in the biological, ecological, and environmental sciences. BioOne provides a sustainable online platform for over 170 journals and books published by nonprofit societies, associations, museums, institutions, and presses.

Your use of this PDF, the BioOne Web site, and all posted and associated content indicates your acceptance of BioOne's Terms of Use, available at www.bioone.org/page/ terms of use.

Usage of BioOne content is strictly limited to personal, educational, and non-commercial use. Commercial inquiries or rights and permissions requests should be directed to the individual publisher as copyright holder. 


\title{
SPECIES DIFFERENCES IN THE SONGS OF THE CRITICALLY ENDANGERED NICEFORO'S WREN AND THE RELATED RUFOUS-AND-WHITE WREN
}

\author{
Sandra V. VAlderrama ${ }^{1,2,3,4}$, Jorge E. Parra ${ }^{1,2}$, And Daniel J. Mennill ${ }^{3,5}$ \\ ${ }^{1}$ Universidad de Los Andes, Carrera $1 N^{\circ} 18 A-10$, Bogotá, Colombia \\ ${ }^{2}$ Fundación ProAves Colombia, Carrera 20 N³6-61, Bogotá, Colombia \\ ${ }^{3}$ Biology Department, University of Windsor, Windsor, Ontario, Canada
}

\begin{abstract}
Niceforo's Wrens (Thryothorus nicefori) and Rufous-and-white Wrens (Thryothorus rufalbus) are closely related Neotropical birds. Niceforo's Wrens, critically endangered endemic Colombian songbirds, are generally considered a sister species to Rufous-and-white Wrens, although some have suggested that they may represent a wellmarked race. A careful comparison of the two taxa has never been conducted. Here we present a thorough study of the songs of male Niceforo's and Rufous-and-white Wrens based on recordings collected throughout both species' geographic ranges. Both species sing low-pitched songs composed of varied pure tone whistles. Niceforo's Wren songs are shorter and simpler with fewer syllables and syllable types; they have higher frequency trills and terminal syllables; and they have distinctive terminal syllables with a broader bandwidth, higher frequency of maximum amplitude, and a larger number of frequency modulations. Discriminant analysis based on fine structural details of songs differentiates the two species. In a subspecies-level discriminant analysis, all five subspecies of Rufousand-white Wren cluster together and are distinct from Niceforo's Wren. Comparisons of morphometric measurements and plumage features reveal parallel differences in body size (Niceforo's Wrens are larger for most measurements) and plumage color (Niceforo's Wrens are more gray than Rufous-and-white Wrens). This study is the first to compare Rufous-and-white versus Niceforo's Wrens with a quantitative approach and supports the idea that these taxa are best understood as distinct species.
\end{abstract}

Key words: endangered species, Niceforo's Wren, Rufous-and-white Wren, Thryothorus wrens, vocal communication.

\section{Diferencias entre los cantos de Thryothorus nicefori críticamente amenazado y Thryothorus rufalbus}

Resumen. Thryothorus nicefori y Thryothorus rufalbus son dos especies de aves Neotropicales estrechamente relacionadas. T. nicefori, un ave canora endémica de Colombia y en peligro crítico, es considerado una especie hermana de T. rufalbus, aunque hay quienes han sugerido que puede representar una raza bien marcada. Ningún trabajo comparando las dos especies ha sido conducido aun. Aquí presentamos un estudio cuidadoso de los cantos de machos de ambas especies basado en grabaciones colectadas a través de su distribución geográfica. Las dos especies emiten cantos a bajas frecuencias, compuestos por silbidos de tonos puros y variados. Los cantos de T. nicefori son más cortos y más simples con menos sílabas así como tipos de sílabas; tienen sílabas terminales y trinos de frecuencias más altas; y sílabas terminales con un ancho de banda más amplio, frecuencia de máxima amplitud más alta, y un número mayor de modulaciones de frecuencia. Los análisis de función discriminante con base en las características estructurales de los cantos diferencian las dos especies. En un análisis discriminante a nivel de subespecie, las cinco subspecies de $T$. rufalbus se agrupan juntas y son distintas de $T$. nicefori. Las comparaciones de las medidas morfométricas y rasgos del plumaje revelan diferencias paralelas en el tamaño del cuerpo (los individuos de $T$. nicefori son más grandes en la mayoría de las medidas) y el color del plumaje (Los individuos de T. nicefori son marcadamente más grises que los individuos de T. rufalbus). Este estudio es el primero que compara a $T$. rufalbus versus $T$. nicefori mediante una aproximación cuantitativa y soporta la idea de que estos taxa son mejor comprendidos como especies distintas.

Manuscript received 5 April 2007; accepted 7 September 2007.

${ }^{4}$ Email: svalderrama@proaves.org

${ }^{5}$ Email: dmennill@uwindsor.ca 


\section{INTRODUCTION}

Acoustic communication in birds plays an important role in evolutionary processes, with a direct function in species recognition and mate choice. Vocal divergence may represent a premating isolation mechanism contributing to speciation, and differences in vocal characteristics should reflect patterns of gene flow and species limits (Slabbekoorn and Smith 2002, Remsen 2005). Although vocal divergence is often discrete among suboscine songbirds, which inherit songs genetically, the situation is more complex with oscine birds, which inherit songs culturally. Nonetheless, the predisposition for oscine songbirds to learn songs from their parental population permits analyses of macrogeographic patterns among oscine species using variation in song (Remsen 2005).

Niceforo's Wrens (Thryothorus nicefori) are oscine songbirds endemic to the Neotropical dry forests of the Chicamocha valley in Colombia (Hilty and Brown 1986). Niceforo's Wrens are restricted to the riparian forest fragments in the Chicamocha region at elevations between $1132 \mathrm{~m}$ and $1840 \mathrm{~m}$ (Valderrama et al. 2007). The World Conservation Union (IUCN) designates Niceforo's Wrens as a Red Listed, critically endangered species because of ongoing anthropogenic habitat modification (IUCN 2006). The extant population consists of fewer than 50 individuals (BirdLife International 2000). Although the species was first described in 1946, the relationship between Niceforo's Wrens and other Thryothorus wrens was not initially recognized, except for a comment about similarity to the Rufous-and-white Wren (Thryothorus rufalbus; Meyer de Schauensee 1946). Presently, the Rufous-and-white Wren is considered the closest taxonomic relative of the Niceforo's Wren (Brewer 2001). Although these sister taxa are often treated as distinct species, a lack of information on the habits and genetics of Niceforo's Wrens has led some to question whether they may represent a race of Rufous-and-white Wren (Ridgeley et al. 1989, Brewer 2001) rather than a separate species.

There are five subspecies of Rufous-andwhite Wrens found along the Pacific coast of Central America-three found from Mexico to Panama (T. r. transfinis, T. r. rufalbus and T. $r$. castanonotus) and two in northern South
America, in Colombia and Venezuela (T. $r$. cumanensis and T. r. minlosi; Brewer 2001). The songs and vocal behavior of both Rufous-andwhite Wrens (T. r. castanonotus; Mennill and Vehrencamp 2005) and Niceforo's Wrens (Valderrama et al. 2008) have only recently been described in detail.

We studied geographic variation in vocalizations of Niceforo's and Rufous-and-white Wrens and compared the fine structural features of their songs. We included songs throughout the geographic range of both species in order to determine whether these species differ in song structure and, if so, what song features separate them. A bioacoustics approach to studying these closely related taxa provides a framework for testing hypotheses on evolutionary divergence and biogeographic patterns. Comparison between Rufous-andwhite and Niceforo's Wrens at a macrogeographic level is important for understanding evolutionary relationships between these taxa and for developing appropriate conservation strategies for Niceforo's Wrens.

\section{METHODS}

\section{SOUND RECORDINGS}

We measured songs recorded from 19 male Niceforo's Wrens from the Chicamocha river valley in the Eastern Andes of Colombia, the only area where Niceforo's Wrens persist (Valderrama et al. 2007). We recorded 1282 songs from eight males between 29 July and 28 December 2004 and 3677 songs from 11 males between 19 July and 9 August 2006 (175 distinct song types from 19 different males; song types defined following Valderrama et al. 2008). Nine birds in the study population were individually marked with distinctive color bands, and the remaining birds were easily distinguished by territory location. Recordings were collected in different areas in 2004 and 2006. We estimate that the 19 recorded birds constitute approximately half of all extant male Niceforo's Wrens (BirdLife International 2000; Valderrama et al. 2008).

For Rufous-and-white Wrens, we measured songs that were gathered from many different locations to encompass the macrogeographic variation of this species as broadly as possible. We measured recordings of $T$. r. transfinis from Mexico (two song types from two individuals); 


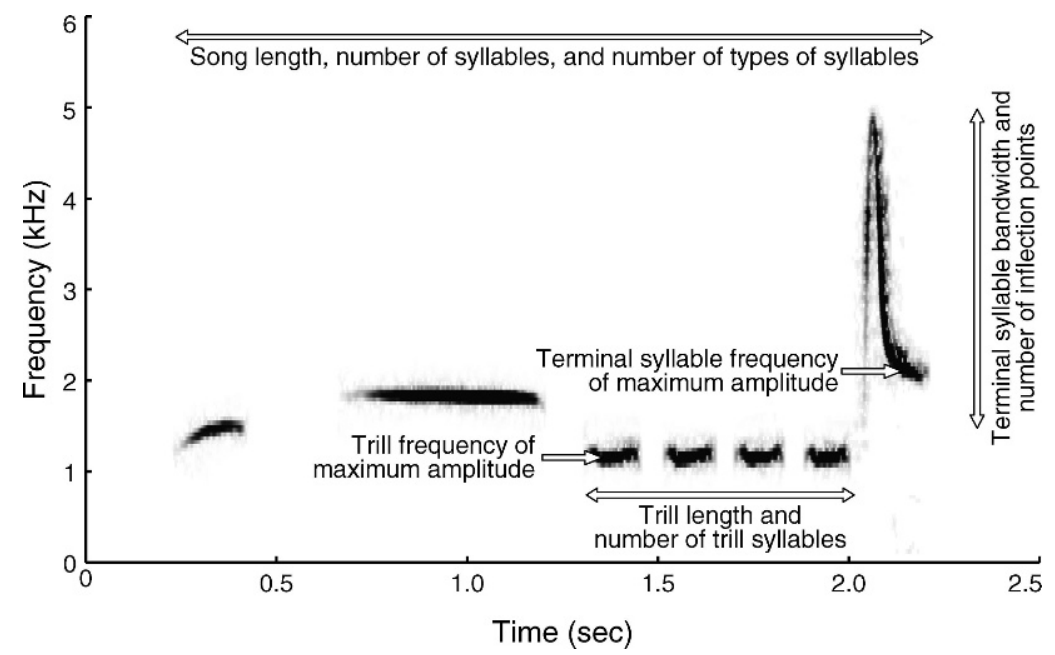

FIGURE 1. Spectrogram of a Niceforo's Wren (Thryothrous nicefori) song, showing the nine fine structural features measured for all songs recorded from both Niceforo's Wrens and Rufous-and-white Wrens (Thryothorus rufalbus).

T. $r$. rufalbus from El Salvador (nine song types from nine individuals); T. r. castanonotus from Nicaragua, Costa Rica, and Panama (136 song types from $\geq 50$ individuals); $T$. $r$. cumanensis from Colombia (15 song types from $\geq 8$ individuals); and T. r. minlosi from Venezuela and Colombia (10 song types from $\geq 5$ individuals). These recordings were obtained by DJM and JP, by other recordists, and from the Macaulay Library at the Cornell Lab of Ornithology. In total, 172 songs from T. rufalbus were compared to the 175 T. nicefori songs.

\section{COMPARISONS BETWEEN SPECIES}

We based analyses on previous vocal studies of both species (Rufous-and-white Wrens: Mennill and Vehrencamp 2005; Niceforo's Wrens: Valderrama et al. 2008). In both Rufous-andwhite and Niceforo's Wrens, males and females sing solo songs, and breeding partners combine their solo songs to produce coordinated duets. A solo song is typically comprised of three parts: varied introductory syllables, a trill with several repeated syllables, and a frequencymodulated terminal syllable. Individuals of both species have repertoires of song types that they sing with eventual variety. In both species, males sing far more often than females, and males have larger repertoire sizes (Mennill and Vehrencamp 2005, Valderrama et al. 2008). We did not obtain adequate sampling from females in most populations of Rufous-and-white Wrens, and hence, we included only male songs in this study.

We used Syrinx-PC (J. Burt, Seattle, Washington) to generate sound spectrograms and measure fine structural features of songs. Song types were identified following Mennill and Vehrencamp (2005) and Valderrama et al. (2008). The highest quality recording of each song type was selected for each individual. To describe the time and frequency characteristics of all recordings, we chose a priori nine variables that could be measured for all recorded songs (Fig. 1). We used Syrinx-PC to measure: (1) total number of syllables, (2) number of syllable types, (3) the number of trill syllables, (4) song length, (5) trill length, and (6) bandwidth of the terminal syllable (maximum minus minimum frequency). We used Audition (Adobe Systems, Inc., San Jose, California) to measure: (7) frequency of maximum amplitude of the trill and (8) frequency of maximum amplitude of the terminal syllable. We also quantified (9) the number of frequency modulations in the terminal syllable. Time measurements were made with a frequency resolution of $0.05 \mathrm{sec}$, and frequency measurements were made with a frequency resolution of $10 \mathrm{~Hz}$.

We include a comparison of plumage color and body size for 15 male Niceforo's Wrens and 
TABLE 1. Differences in song structure of Niceforo's Wrens and Rufous-and-white Wrens. Values for each species are given as means $\pm \mathrm{SE}$.

\begin{tabular}{|c|c|c|c|c|}
\hline Variable & $\begin{array}{l}\text { Thryothorus } \\
\text { nicefori }\end{array}$ & $\begin{array}{l}\text { Thryothorus } \\
\text { rufalbus }\end{array}$ & $\begin{array}{c}\text { Mann-Whitney } \\
U\end{array}$ & $P$ \\
\hline Number of syllables & $9.9 \pm 0.5$ & $14.9 \pm 0.5$ & 7403 & $<0.0001$ \\
\hline Number of syllable types & $3.6 \pm 0.1$ & $4.2 \pm 0.1$ & 10058 & $<0.0001$ \\
\hline Trill number of syllables & $7.1 \pm 0.4$ & $10.5 \pm 0.5$ & 9064 & $<0.0001$ \\
\hline Song length (sec) & $1.91 \pm 0.03$ & $2.29 \pm 0.04$ & 8994 & $<0.0001$ \\
\hline Trill length $(\mathrm{sec})$ & $0.69 \pm 0.02$ & $0.96 \pm 0.02$ & 6001 & $<0.0001$ \\
\hline Trill frequency of maximum amplitude $(\mathrm{Hz})$ & $1042 \pm 5$ & $930 \pm 7$ & 3758 & $<0.0001$ \\
\hline $\begin{array}{l}\text { Terminal syllable frequency of maximum } \\
\text { amplitude }(\mathrm{Hz})\end{array}$ & $1944 \pm 48$ & $1582 \pm 42$ & 9380 & $<0.0001$ \\
\hline Terminal syllable bandwidth $(\mathrm{Hz})$ & $930 \pm 53$ & $640 \pm 37$ & 9475 & $<0.0001$ \\
\hline $\begin{array}{l}\text { Terminal syllable number of frequency } \\
\text { modulations }\end{array}$ & $1.75 \pm 0.08$ & $0.76 \pm 0.05$ & 106 & $<0.0001$ \\
\hline
\end{tabular}

30 male Rufous-and-white Wrens of subspecies castonanotus (from Santa Rosa National Park, Costa Rica). No data are available on body size or plumage color for the five other rufalbus subspecies, and consequently, this comparison has limited scope. Morphometric data were collected from live birds captured with mist nets. We measured mass with a spring scale $( \pm 1 \mathrm{~g})$, tail and wing length with a steel rule $( \pm 1 \mathrm{~mm})$, and tarsus length with a dial caliper $( \pm 0.1 \mathrm{~mm})$.

\section{STATISTICAL ANALYSES}

We examined variation in songs between species using canonical discriminant analysis with JMP ${ }^{\circledR} 5.1$ (SAS Institute, Cary, North Carolina). We performed two discriminant analyses - one at the species level (T. rufalbus and $T$. nicefori) and one at the subspecies level (all six $T$. rufalbus subspecies and the single $T$. nicefori taxon). For both discriminant analyses, we used all nine fine structural measures outlined above to construct discriminant functions on a randomly selected subset of $80 \%$ of all measured songs. We cross-validated the discriminant analyses by testing the accuracy of assigning songs to the correct species or subspecies with the remaining $20 \%$ of songs. We report the accuracy of the discriminant analyses as the percentage of songs assigned to the correct species or subspecies for this $20 \%$ of songs. Because we analyzed a different number of songs for each rufalbus subspecies, the subspecies-level discriminant analysis is useful for detecting differences between nicefori and the six rufalbus subspecies, but not for detecting differences among the six rufalbus subspecies.
All tests are two-tailed and use a significance level of $P=0.05$, except for the nine comparisons presented in Table 1, where we use a significance level adjusted to $P=0.006$. All values are reported as means $\pm \mathrm{SE}$.

\section{RESULTS}

\section{SPECIES DIFFERENCES IN SONG STRUCTURE}

Niceforo's Wrens and Rufous-and-white Wrens show substantial differences in the fine structure of male songs (Fig. 2). Niceforo's Wren songs contain significantly fewer total syllables, fewer syllable types, and fewer trill syllables than those of Rufous-and-white Wrens. Niceforo's Wren songs are significantly shorter, both in total length and in trill length. Niceforo's Wren songs are significantly higher pitched, with a higher trill frequency of maximum amplitude and terminal syllable frequency of maximum amplitude, and show a broader bandwidth and higher number of frequency modulations in the terminal syllable (Table 1). Discriminant analysis separated the songs of Niceforo's Wrens from Rufous-andwhite Wrens (Fig. 3A). This analysis assigned songs to the correct species with $94 \%$ accuracy. The first canonical axis explained $100 \%$ of the variation between these taxa and was heavily influenced by trill length as well as number of frequency modulations in the terminal syllable (Table 2).

Discriminant analysis on the basis of subspecies revealed substantial overlap between each of the Rufous-and-white Wren subspecies but substantial difference from Niceforo's Wrens (Fig. 3B). This analysis assigned songs 


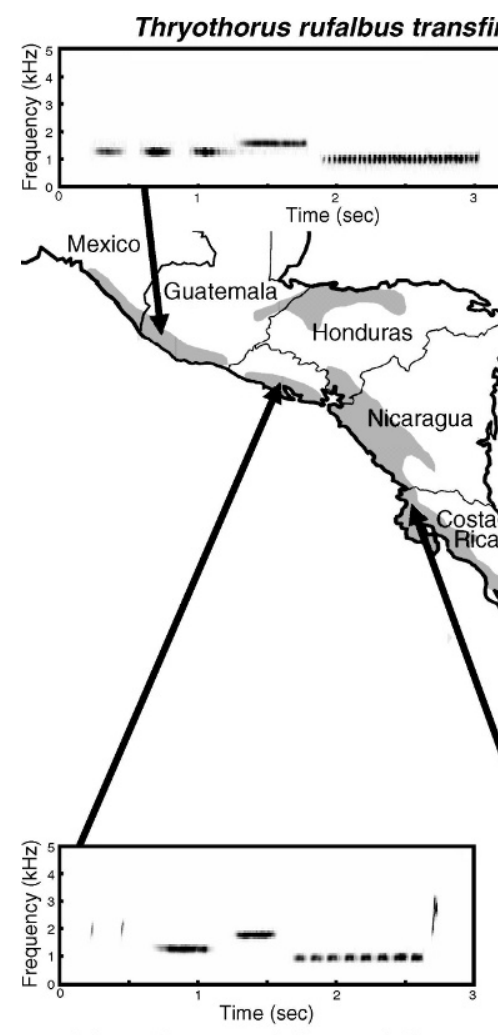

Thryothorus rufalbus rufalbus

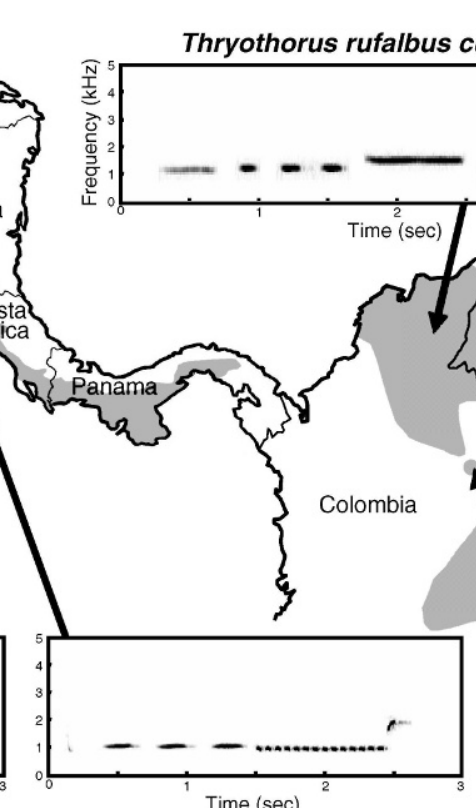

Thryothorus rufalbus castonanotus
Thryothorus rufalbus minlosi

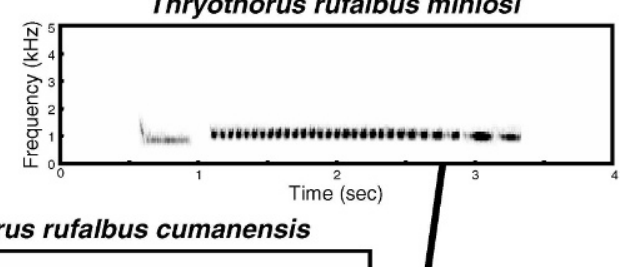

FIGURE 2. Spectrograms demonstrating patterns of geographic variation in the songs of Rufous-and-white Wrens (Thryothorus rufalbus) and Niceforo's Wrens (Thryothorus nicefori). Spectrograms are joined with lines to locations where songs were recorded. Shaded regions show the entire geographic distribution of the five subspecies of Rufous-and-white Wrens and the limited geographic range of Niceforo's Wrens in Colombia.

to the correct subspecies with $80 \%$ accuracy and assigned songs to the correct species with $97 \%$ accuracy. The first two canonical axes explained $91 \%$ of the variation between subspecies and were heavily influenced by trill length and number of frequency modulations in terminal syllables (canonical axis 1) and by song length, number of syllable types, and trill length (canonical axis 2; Table 3).

\section{SPECIES DIFFERENCES IN PLUMAGE AND MORPHOLOGY}

These differences in song structure are paralleled by differences in plumage and morphology revealed through comparison of Niceforo's Wrens and one subspecies of Rufous-and-white Wren (T. r. castanonotus; $n=15$ and 30 males, respectively). The back, nape, and crown are distinctly grayish-brown in Niceforo's Wrens and distinctly reddish-brown in Rufous-and- white Wrens. Male Niceforo's Wrens are heavier than male Rufous-and-white Wrens (T. nicefori: $27.2 \pm 0.5 \mathrm{~g} ; T$. r. castanonotus: $\left.25.1 \pm 0.2 \mathrm{~g} ; t_{44}=2.0, P=0.05\right)$, have slightly shorter wings (T. nicefori: $68.7 \pm 0.5 \mathrm{~mm} ; T$. $r$. castanonotus: $69.8 \pm 0.3 \mathrm{~mm} ; t_{44}=2.0 P=$ 0.05 ), longer tails ( $T$. nicefori: $58.4 \pm 0.6 \mathrm{~mm}$; T. r. castanonotus: $51.0 \pm 0.4 \mathrm{~mm} ; t_{44}=11.0 P$ $<0.001$ ), and shorter tarsi (T. nicefori: $21.3 \pm$ $0.2 \mathrm{~mm} ;$ T. $r$. castanonotus: $22.8 \pm 0.4 \mathrm{~mm} ; t_{44}$ $=3.6 P=0.03)$.

\section{DISCUSSION}

The songs of Niceforo's Wrens and Rufousand-white Wrens show distinct fine structural properties. These two species sound similar, especially when compared to other Thryothorus wrens that sing high-pitched, staccato songs, yet Niceforo's and Rufous-and-white Wrens are easily distinguished from each other by dis- 

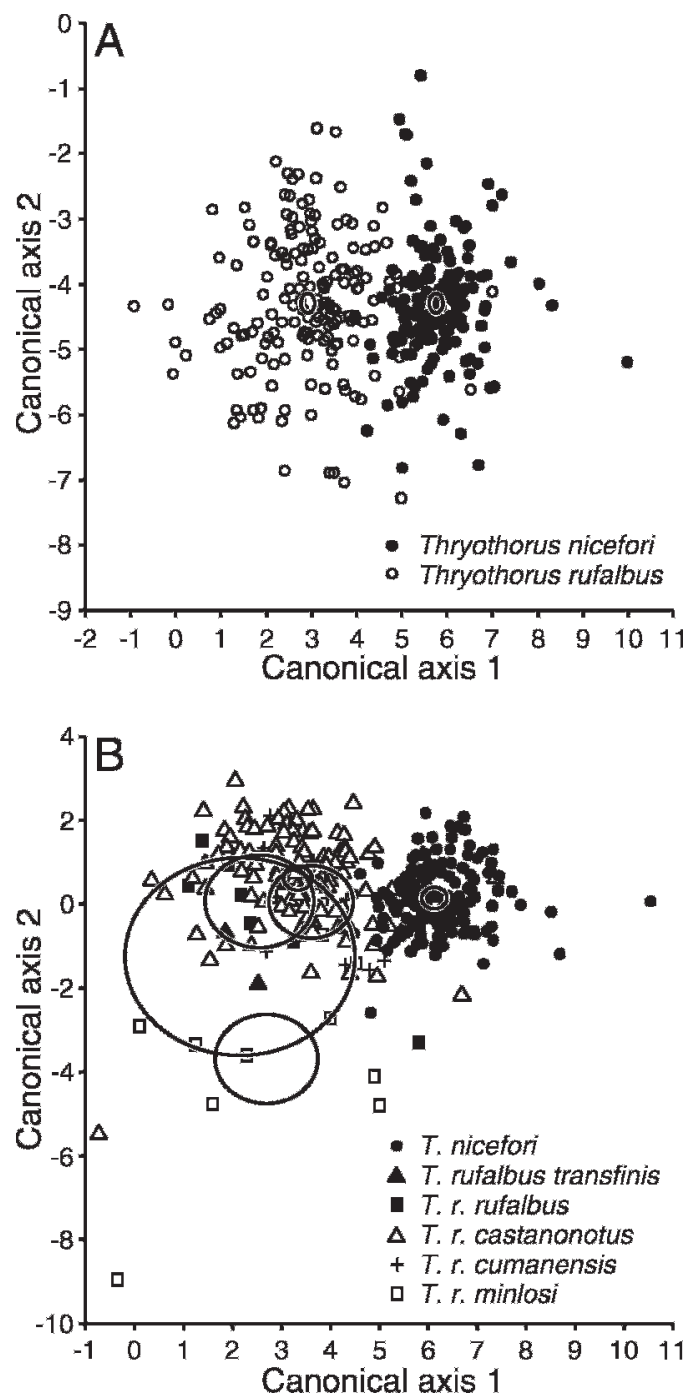

FIGURE 3. Scatterplots of the two canonical discriminant functions resulting from the discriminant analysis (A) between Rufous-and-white Wrens (Thryothorus rufalbus) and Niceforo's Wrens (Thryothorus nicefori) and (B) between five subspecies of Rufous-and-white Wren and Niceforo's Wren. All measured songs are depicted. Ellipses show $95 \%$ confidence limits for the multivariate mean of each group.

criminant analyses. The differences in song structure that we detected in our analyses support the idea that Niceforo's Wrens and Rufous-and-white Wrens should be considered distinct species.

Variation in song structure between groups provides insight for understanding species di-
TABLE 2. Discriminant analysis of Niceforo's Wrens and Rufous-and-white Wrens based on nine fine structural features of male songs. Variables with the strongest loadings are indicated with asterisks.

\begin{tabular}{lcc}
\hline \hline & \multicolumn{2}{c}{$\begin{array}{c}\text { Canonical discrim- } \\
\text { inant function }\end{array}$} \\
\cline { 2 - 3 } \multicolumn{1}{c}{ Variable } & 1 & 2 \\
\hline Number of syllables & -0.20 & 0.53 \\
Number of syllable types & -0.47 & 0.48 \\
Trill number of syllables & 0.17 & 0.56 \\
Song length (sec) & 0.11 & 0.44 \\
Trill length (sec) & $-2.27 *$ & 0.01 \\
Trill frequency of maximum & 0.01 & 0.00 \\
$\quad$ amplitude (Hz) & & \\
$\begin{array}{l}\text { Terminal syllable frequency of } \\
\quad \text { maximum amplitude (Hz) }\end{array}$ & 0.00 & 0.00 \\
$\begin{array}{l}\text { Terminal syllable bandwidth (Hz) } \\
\text { Terminal syllable number of }\end{array}$ & 0.00 & 0.00 \\
$\quad$ frequency modulations & $0.77 *$ & 0.11 \\
$\begin{array}{l}\text { Eigenvalue } \\
\text { \% of variance explained }\end{array}$ & 2.09 & 0.00 \\
\hline
\end{tabular}

vergence. Vocal divergence between allopatric and parapatric populations may be due to habitat differences (Slabbekoorn and Smith 2002), character displacement, and sound production constraints due to morphological differences (Podos and Nowicki 2004). Additionally, in oscines, vocal geographic variation involves cultural variation, such that song variation in songbirds may influence allopatric speciation rates (Lachlan and Servedio 2004).

TABLE 3. Discriminant analysis of Niceforo's Wrens and five subspecies of Rufous-and-white Wrens based on nine fine structural features of male songs. Variables with the strongest loadings are indicated with asterisks.

\begin{tabular}{lcc}
\hline \hline & \multicolumn{2}{c}{$\begin{array}{c}\text { Canonical discrim- } \\
\text { inant function }\end{array}$} \\
\cline { 2 - 3 } \multicolumn{1}{c}{ Variable } & 1 & 2 \\
\hline Number of syllables & -0.33 & -0.37 \\
Number of syllable types & -0.30 & $1.46^{*}$ \\
Trill number of syllables & 0.32 & 0.40 \\
Song length (s) & 0.36 & $-1.77^{*}$ \\
Trill length (s) & $-2.97^{*}$ & $0.99^{*}$ \\
Trill frequency of maximum & 0.01 & 0.00 \\
$\quad$ amplitude (Hz) & & \\
Terminal syllable frequency of & 0.00 & 0.00 \\
$\quad$ maximum amplitude (Hz) & & \\
Terminal syllable bandwidth (Hz) & 0.00 & 0.00 \\
Terminal syllable number of & $0.71 *$ & 0.12 \\
$\quad$ frequency modulations & & \\
$\begin{array}{l}\text { Eigenvalue } \\
\text { \% of variance explained }\end{array}$ & 68 & 2.09 \\
\hline & & 0.66 \\
\hline
\end{tabular}


The differences in song structure found between Niceforo's Wrens and Rufous-and-white Wrens may have resulted from the influence of one or more such factors causing vocal divergence. Cultural drift in allopatric populations may also contribute to the observed differences in song structure.

Niceforo's Wren habitat has been fragmented in the past by natural barriers and, more recently, by anthropogenic modification. The Chicamocha region is characterized by a deep valley and steep slopes with stratified and distinctive climate and vegetation. Organisms living in this region are isolated not only by valleys but by peripheral mountains more than $2300 \mathrm{~m}$ in elevation. These mountains produce a rain shadow at lower elevations and local drought conditions that shape the dry Neotropical forest habitat (Halffter 1992, Albesiano and Fernandez-Alonso 2006). Other endemic species in the Chicamocha region include the Santander coral snake (Micrurus sangilensis), and the San Gil mushroomtongue salamander (Bolitoglossa nicefori; Hernández et al. 1992). As such, the Chicamocha region is an isolated area that supports a unique community of species. Both before and after the arrival of the Spanish, humans have modified the landscape of the Chicamocha region (Etter and Villa 2000). Habitat differences due to historical anthropogenic effects may have contributed to the evolutionary divergence of Niceforo's Wrens.

Isolation has been demonstrated to influence vocalizations. The effects of isolation on bird songs have been investigated by comparing island populations with their mainland counterparts (Thielcke 1973, Kroodsma 1985, Naugler and Smith 1991, Hamao and Ueda 2000, Baker et al. 2006). Findings have revealed less complex songs in island relative to mainland populations. Habitat fragments can be regarded as islands, and isolation due to habitat patchiness may also reduce acoustic diversity (Laiolo and Tella 2006). In this way, the songs of Niceforo's Wrens may have been influenced by habitat fragmentation, which would be reflected in song complexity and possibly other song traits, including frequency.

Sound transmission is influenced by habitat differences. Higher frequency sounds have better transmission through open habitats, whereas lower frequency sounds have better transmission in forested habitats (Morton 1975, Wiley and Richards 1978). Narrow-bandwidth sounds and longer notes appear to maximize signal transmission in dense tropical forest (Slabbekoorn and Smith 2002). Frequency modulation has been emphasized as an important feature in comparative studies to understand evolutionary processes related to habitat influence in sound transmission, such as signal convergence and divergence (Slabbekoorn and Smith 2002). The higher frequency characteristics and more frequency modulated terminal syllables of Niceforo's Wrens songs may suggest that transmission properties of different habitats have played a role in the divergence of these species, and future research should quantify differences in habitat and sound transmission between Niceforo's and Rufousand-white Wrens.

The differences we revealed in the songs of male Niceforo's and Rufous-and-white Wrens mirror physical differences observed in Niceforo's Wrens and the only subspecies of Rufous-and-white Wren (T. r. castanonotus) for which detailed measurements are available. Although these features have not been studied in detail, our field measurements show prominent differences between these taxa for all of the morphometric features we measured. Plumage color also differs notably between these taxa. As Meyer de Schauensee (1946) noted in the first description of Niceforo's Wrens, "the coloration is totally different" from Rufousand-white Wrens. Future genetic research, complementing the recent molecular phylogeny of many species of Thryothorus wrens (Mann et al. 2006) will further elucidate the distinctiveness of Niceforo's and Rufous-and-white Wrens.

Our results underscore the importance of preserving the remnant population of Niceforo's Wrens in Colombia's Chicamocha Valley as a unique species. Niceforo's Wrens are very vulnerable to extinction due to the unchecked destruction of their dry forest habitat. Maintaining and regenerating forest fragments are crucial actions in order to initiate conservation and recovery actions for this species.

\section{ACKNOWLEDGMENTS}

This research was supported by a grant from the Association of Universities and Colleges of Canada to DJM. We thank Fundación ProAves Colombia, 
the University of Windsor, and the Natural Science of Engineering Research Council of Canada (NSERC) for additional support. Niceforo's Wren recordings were obtained during research by SVV and JEP with support from the BP Conservation Program, Fundación ProAves Colombia, and The British Library. For contributing Rufous-and-white Wren recordings, we are very grateful to $\mathrm{N}$. Anthanas, D. Bradley, D. Gammon, D. Gousig, J. P. Kjeldsen, O. Laverde, M. Libsch, D. Logue, M. Mark, R. Martin, E. Morton, W. Naranjo, and C. Parrish, and to the Macaulay Library at the Cornell Lab of Ornithology. We thank two anonymous reviewers for comments on the manuscript. SVV thanks D. Bradley for his valuable support during the writing of this manuscript.

\section{LITERATURE CITED}

Albesiano, S., And J. L. Fernández-Alonso. 2006. Catalogue of the vascular plants from the Chicamocha River canyon (tropical zone), Boyacá-Santander, Colombia. Caldasia 28:23-44.

BAKer, M. C., M. S. A. BAKER, AND L. M. Tilgham. 2006. Differing effects of isolation on evolution of bird songs: examples from an island-mainland comparison of three species. Biological Journal of the Linnean Society 89:331-342.

BIRDLIFE INTERNATIONAL. 2000. Threatened birds of the world. Lynx Editions and BirdLife International, Barcelona, Spain and Cambridge, UK.

BREWER, D. 2001. Wrens, dippers and thrashers. Yale University Press, New Haven, CT.

EtTer, A., AND L. A. Villa. 2000. Andean forests and farming systems in part of the Eastern Cordillera (Colombia). Mountain Research and Development 20:236-245.

HAlFFTER, G. [ED.]. 1992. La diversidad biológica de Iberoamerica. Vol. I. Acta Zoológica Mexicana, volumen especial. Instituto de Ecología, AC, Xalapa, Mexico.

Hamao, S., And K. Ueda. 2000. Simplified song in an island population of the bush warbler Cettia diphone. Journal of Ethology 18:53-57.

Hilty, S. L., AND W. L. Brown. 1986. A guide to the birds of Colombia. Princeton University Press, Princeton, NJ.

INTERNATIONAL UNION FOR THE CONSERVATION OF NATURE AND NATURAL ResourCes. 2006. IUCN Red List of Threatened Species <www. iucnredlist.org > (21 March 2007).

Kroodsma, D. E. 1985. Geographic variation in songs of the Bewick's Wren: a search for correlations with avifaunal complexity. Behavioral Ecology and Sociobiology 16:143-150.

LAChlan, R. F., AND M. R. SERVEdio. 2004. Song learning accelerates allopatric speciation. Evolution 58:2049-2063.

LAiolo, P., AND J. L. Tella. 2006. Landscape bioacoustics allow detection of the effects of habitat patchiness on population structure. Ecology 87:1203-1214.

Mann, N. I., F. K. Barker, J. A. Graves, K. A. Dingess-Mann, And P. J. B. Slater. 2006. Molecular data delineate four genera of "Thryothorus" wrens. Molecular Phylogenetics and Evolution 40:750-759.

Mennill, D. J., And S. Vehrencamp. 2005. Sex differences in singing and duetting behavior of neotropical Rufous-and-white Wrens (Thryothorus rufalbus). 2005. The Auk 122:175-186.

Meyer de Schauensee, R. 1946. A new species of wren from Colombia. Notulae Naturae $161: 1-14$.

MorTON, E. S. 1975. Ecological sources of selection on avian sounds. American Naturalist 109:17-34.

Naugler, C. T., AND P. C. Smith. 1991. Song similarity in an isolated population of Fox Sparrows (Passerella iliaca). Condor 93:1001-1003.

Podos, J., AND S. Nowicki. 2004. Beaks, adaptation and vocal evolution in Darwin's finches. BioScience 54:501-510.

REMSEN, J. V., JR. 2005. Pattern, process, and rigor meet classification. The Auk 122:403-413.

Ridgely, R., G. Tudor, AND W. L. Brown. 1989. The Birds of South America. Vol. 1. University of Texas Press, Austin, TX.

Slabbekoorn, H., AND T. B. SMith. 2002. Bird song, ecology and speciation. Philosophical Transactions of the Royal Society of London Series B 357:493-503.

ThiELCKE, G. 1973. On the origin of learned signals in isolated populations. Ibis 115:511-516.

Valderrama, S. V., J. E. Parra, And N. Davila. 2007. First nest description for Niceforo's Wren (Thryothorus nicefori): a critically endangered Colombian endemic songbird. Ornitologia Neotropical 18:313-318.

Valderrama, S. V., J. E. Parra, N. Davila, And D. J. MenniLl. 2008. The vocal behavior of the critically endangered Niceforo's Wren Thryothorus nicefori. Auk 128, in press.

Wiley, R. H., AND D. G. Richards. 1978. Physical constraints on acoustic communication in the atmosphere: implications for the evolution of animal vocalizations. Behavioral Ecology and Sociobiology 3:69-94. 